\title{
STUDI KUAT TEKAN DAN KUAT TARIK BELAH BETON DENGAN \\ MENGGUNAKAN POTONGAN LIMBAH SPANDUK SEBAGAI BAHAN \\ TAMBAH
}

\author{
Usman \\ Alumni Jurusan Teknik Sipil Universitas Bangka Belitung \\ Email : usmanvelasebri@gmail.com \\ Donny Fransiskus Manalu \\ Staf Pengajar Jurusan Teknik Sipil Universitas Bangka Belitung \\ Email : donny_fm@yahoo.com
}

Yayuk Apriyanti

Dosen Teknik Sipil Universitas Bangka Belitung

Email : yayukapriyanti26@gmail.com

\begin{abstract}
INTISARI
Bertambahnya jumlah penduduk yang ada di Indonesia, bertambah juga kebutuhan manusia akan struktur bangunan, terutama beton. Beton, selain baja dan kayu, juga sangat banyak dipakai secara luas sebagai salah satu bahan bangunan, seperti bangunan gedung perkantoran, perhotelan, rumah sakit, dan lain sebagainya. Jadi, hampir setiap pembangunan memanfaatkan beton sebagai bahan utama dalam pembangunan tersebut. Adapun salah satu alasan penggunaan beton adalah beton termasuk bahan yang awet, tahan aus, tahan kebakaran, tahan terhadap pengkaratan atau pembusukan oleh lingkungan, dan juga biaya perawatan murah. Penelitian ini bertujuan untuk mengetahui nilai kuat tekan dan kuat tarik belah beton dengan menggunakan potongan limbah spanduk sebagai bahan tambah. Serat spanduk yang dipakai pada penelitian ini adalah serat spanduk yang berbahan dasar polyvinylclorida dan terdapat serat nylon didalam spanduk. Serat spanduk berukuran persegi panjang dengan panjang $35 \mathrm{~mm}$ dan lebar $10 \mathrm{~mm}$. Mutu beton yang direncanakan sebesar f'c 20 MPa. Persentase penambahan spanduk sebesar 0\%, 0,15\% dan 0,45\% dari perbandingan berat rencana beton. Umur beton yang digunakan yaitu 7 dan 28 hari untuk kuat tekan, sedangkan kuat tarik belah beton umur 28 hari. Hasil penelitian kuat tekan beton umur 7 berturut-turut sebesar 19,355 MPa, 15,114 MPa, dan 13,141 MPa, umur 28 hari berturut-turut sebesar 20,413 MPa, 17,985 MPa dan 12,942. Nilai kuat tarik belah beton umur 28 hari berturut-turut sebesar 2,467 MPa, 2,161 MPa dan 2,220 MPa. Penambahan serat spanduk untuk bahan tambah beton tidak baik untuk pembuatan beton karena kuat tekan dan kuat tarik belah beton selalu menurun.
\end{abstract}

Kata Kunci : Beton,serat spanduk, kuat tekan beton dan kuat tarik belah beton 


\section{PENDAHULUAN}

\section{Latar Belakang}

Bertambahnya jumlah penduduk yang ada di Indonesia, bertambah juga kebutuhan manusia akan struktur bangunan, terutama beton. Banyak hal yang dapat dilakukan dengan beton dalam kontruksi bangunan, contohnya dalam struktur beton yang terdiri dari balok, kolom, pondasi atau pelat.

Beton, selain baja dan kayu, juga sangat banyak dipakai secara luas sebagai salah satu bahan bangunan, seperti bangunan gedung perkantoran, perhotelan, rumah sakit, dan lain sebagainya. Jadi, hampir setiap pembangunan memanfaatkan beton sebagai bahan utama dalam pembangunan tersebut. Adapun salah satu alasan penggunaan beton adalah beton termasuk bahan yang awet, tahan aus, tahan kebakaran, tahan terhadap pengkaratan atau pembusukan oleh lingkungan, dan juga biaya perawatan murah.

Berdasarkan ACI (American Concrete Institute), bahan tambah adalah material selain air, agregat dan semen yang dicampurkan dalam beton atau mortar yang ditambahkan sebelum atau selama pengadukan. Tujuan pemberian bahan tambah ialah untuk menghasilkan beton khusus yang lebih baik dari beton normal, baik itu kuat tekan dan kuat tariknya maupun nilai slump. Bahan tambah berupa serat menurut Tjokrodimurljo, K., (2007), maksud utama penambahan serat ke dalam beton adalah untuk menambah kuat tarik, karena beton merupakan bahan yang kuat tariknya rendah.

Berdasarkan keputusan Menprindag RI No. 231/MPP/Kep/7/1997 Pasal 1 tentang prosedur impor limbah, menyatakan bahwa limbah adalah bahan/barang sisa atau bekas dari suatu kegiatan atau proses produksi yang fungsinya sudah berubah dari aslinya, kecuali yang dapat dimakan oleh manusia dan hewan. Salah satu limbah atau sampah yang sulit didaur ulang adalah limbah padat. Limbah padat adalah sisa hasil kegiatan industri ataupun aktivitas domestik yang berbentuk padat. Limbah atau sampah spanduk merupakan limbah padat yang sulit terurai dan apabila dibakar akan menimbulkan polusi udara yang terkadung dalam asap yang berakibat dapat bisa menimbulkan penyakit dalam tubuh manusia bila menghirup udara tersebut.

Spanduk merupakan suatu kain rentang yang isinya propaganda, slogan atau berita yang perlu diketahui oleh umum atau orang banyak. Spanduk pada jaman sekarang ini sebagai media promosi yang cukup populer, karena harganya yang cukup murah serta proses pengerjaanya yang sangat cepat dan spanduk juga media promosi yang cukup ampuh dalam mempromosikan suatu barang. Dari banyaknya permintaan akan spanduk pada sekarang ini, banyak muncul perusahaan - perusahaan yang bergerak di bidang periklanan serta memiliki mesin Digital Print sendiri untuk membuatnya atau mencetak spanduk. Dari bertambah banyaknya jumlah perusahaan percetakan spanduk, bertambah pula akan jumlah limbah/sampah dari hasil percetakan spanduk yang berupa potongan-potongan yang tidak terpakai atau termanfaatkan lagi atau potongan yang telah dibuang di tong sampah. 


\section{Rumusan Masalah}

Berdasarkan uraian latar belakang diatas permasalahan yang akan dibahas dalam penelitian ini adalah sebagai berikut ini.

1. Bagaimana nilai kuat tekan beton dengan menggunakan potongan limbah spanduk sebagai bahan tambah?

2. Bagaimana nilai kuat tarik belah beton dengan menggunakan potongan limbah spanduk sebagai bahan tambah?

\section{Batasan Penelitian}

Tahapan pelaksanaan penelitian ini tidak dilakukan percobaan dilapangan namun dibatasi pada percobaan di laboratorium dengan batasan masalah sebagai berikut ini.

\section{Potongan spanduk pada penelitian ini} berasal dari sisa potongan-potongan hasil percetakan dari tempat percetakan spanduk yang ada di Pangkalpinang, dan juga diambil dari sisa spanduk yang ada di kampus Universitas Bangka Belitung.

2. Potongan spanduk yang akan digunakan berbentuk persegi panjang dengan ukuran panjang $35 \mathrm{~mm}$, lebar 10 $\mathrm{mm}$.

3. Jenis spanduk yang digunakan dalam penelitian ini adalah spanduk yang berbahan dasar flexy/vynil yaitu berbahan jenis polivinil dan nylon yang membentuk lembaran serat.

4. Semen yang digunakan adalah semen portland komposit (termasuk dalam semen jenis tipe I) merk Tiga Roda.

5. Air yang digunakan yaitu air sumur dari Laboratorium Teknik Sipil Universitas Bangka Belitung.

6. Agregat kasar yang digunakan untuk penelitian ini berasal dari PT. ABI (Aditya
Buana Inter) di Desa Jurung Kabupaten Bangka.

7. Agregat halus yang digunakan untuk penelitian berasal dari Desa Rebo, Kabupaten Bangka.

8. Benda uji berupa silinder dengan ukuran diameter $150 \mathrm{~mm}$ dan tinggi 300 $\mathrm{mm}$.

9. Pengujian yang akan dilakukan pada beton adalah kuat tekan beton pada umur 7 hari dan 28 hari dengan persentase variasi potongan spanduk sebanyak 0\%, 0,15\%, $0,45 \%$ sebagai bahan tambah dari beton sedangkan kuat tarik beton pada umur 28 hari dengan persentase variasi potongan spanduk sebanyak $0 \%, 0,15 \%$, dan $0,45 \%$, terhadap berat rencana beton.

10. Mutu beton yang direncanakan adalah $f^{\prime} c 20 \mathrm{MPa}$.

11. Jumlah benda uji masing-masing 3 buah setiap variasi pemakaian potongan spanduk.

12. Reaksi kimia dari spanduk tidak dibahas dalam penelitian ini.

\section{Tujuan Penelitian}

Adapun tujuan yang hendak dicapai dalam penelitian ini adalah sebagai berikut ini.

1. Mengetahui nilai kuat tekan beton dengan menggunakan limbah potongan spanduk sebagai bahan tambah dari beton.

2. Mengetahui nilai kuat tarik belah beton dengan menggunakan limbah potongan spanduk sebagai bahan tambah.

\section{TINJAUAN PUSTAKA DAN}

\section{LANDASAN TEORI}

Tinjauan Pustaka 
1. Putri, R.N.C., (2016), meneliti tentang pengaruh penambahan potongan limbah banner dengan bentuk potongan memanjang terhadap kuat tekan dan kuat lentur beton.

2. Apriliawati, A., (2016), meneliti tentang kajian kuat lekat dan kuat tekan pada beton serat dengan bahan tambah potongan limbah banner.

3. Hariyanti, N.F., (2016), meneliti tentang pengaruh variasi bentuk potongan limbah banner terhadap kelecakan dan kuat lentur beton serat banner.

4. Pratama, E., (2016), meneliti tentang kajian kuat tekan dan kuat tarik belah beton kertas (papercrete) dengan bahan tambah serat nylon.

5. Suryawan, N., (2014), meneliti tentang pengaruh penambahan serat polypropylene pada beton ringan dengan teknologi foam terhadap kuat tekan, kuat tarik belah dan modulus elastisitas.

\section{Landasan Teori}

\section{Beton Normal}

Berdasarkan SNI 7656-2012, beton merupakan campuran antara semen portland atau semen hidrolis yang lain, agregar halus, agregat kasar dan air dengan atau tanpa bahan tambah, membentuk massa yang padat, kuat dan stabil.

Menurut Tjokrodimuljo.K., (2007), beton dibandingkan dengan bahan bangunan lain mempunyai beberapa kelebihan, antara lain

1. Harganya relatif murah karena menggunakan bahan-bahan yang umumnya tersedia didekat lokasi pembangunan.

2. Termasuk bahan yang awet, tahan aus, tahan kebakaran, tahan terhadap pengkaratan atau pembusukan oleh kondisi lingkungan, sehingga biaya perawatan murah.

3. Kuat tekan cukup tinggi sehingga dikombinasikan dengan baja tulangan (yang kuat tariknya tinggi).

4. Beton segar dapat dengan mudah diangkut maupun dicetak dalam bentuk dan ukuran sesuai keinginan.

Walaupun mempunyai kelebihan, namun beton juga mempunyai kekurangan, di antaranya.

1. Bahan dasar penyusun beton (agregat halus maupun agregat kasar) bermacammacam sesuai dengan lokasi pengambilannya, sehingga cara perencanaan dan cara pembuatannya bermacam-macam pula.

2. Beton keras mempunyai beberapa kelas kekuatan sehingga harus disesuaikan dengan bagian bangunan yang dibuat, cara perencanaan dan pelaksanaannya bermacam-macam pula.

3. Beton mempunyai kuat tarik yang rendah, sehingga getas/rapuh dan mudah retak.

\section{Beton Serat}

Menurut Tjokrodimuljo.K., (2007), mengenai beton serat ialah bagian komposit yang terdiri dari beton biasa dan bahan lain yang berupa serat. Serat pada umunya berupa batang-batang dengan diameter antara 5 dan 500 mikro meter dan panjang sekitar $25 \mathrm{~mm}$ sampai $100 \mathrm{~mm}$. Bahan serat dapat berupa: serat tumbuh-tumbuhan (rami, bambu, ijuk), serat plastik (polypropylene), atau potongan kawat baja. 


\section{Serat Spanduk}

Spanduk merupakan suatu kain rentang yang isinya propaganda, slogan atau berita yang perlu diketahui oleh umum atau orang banyak. Menurut Putri, R.N.C., (2016) banner merupakan media promosi outdoor yang terbuat dari bahan nylon dan polyvinylclorida. Ciri-ciri bahan licin mirip seperti plastik namun memiliki serat nylon yang berfungsi untuk menguatkan struktur vinyl-nya.Menurtu Pine, dkk (1988: 1043) dalam penelitian Putri, R.N.C., (2016) polyvinylclorida adalah polimer yang terbentuk akibat aksi ikat-mengikat dengan ciri kuat dan keras, sedangkan nylon merupakan poliamida buatan yang mempunyai gaya regang yang baik sekali bila dijadikan serat.

\section{Kuat Tekan}

Munurut SNI-03-1974-1990, kuat tekan beton adalah besarnya beban per satuan luas, yang menyebabkan benda uji beton hancur bila dibebani dengan gaya tekan tertentu, yang dihasilkan oleh mesin tekan. Besaran kuat tekan beton didapatkan dengan rumus :

$\mathrm{fc}^{\prime}=\frac{P}{A}\left(\mathrm{~kg} / \mathrm{cm}^{2}\right)$ 1

Dengan:

fc' = kuat tekan beton $\left(\mathrm{kg} / \mathrm{cm}^{2}\right)$

$\mathrm{P} \quad=$ beban maksimum $(\mathrm{kg})$

A = luas penampang $\left(\mathrm{cm}^{2}\right)$

\section{Kuat Tarik Belah}

Kuat tarik belah beton adalah kuat tarik tidak langsung dari benda uji beton yang berbentuk silinder yang diperoleh dari pembebanan benda uji tersebut yang diletakkan mendatar sejajar dengan permukaan meja penekan mesin uji ditekan.
Kuat tarik beton dapat dihitung dengan rumus sebagai berikut :

$\mathrm{ft}=\frac{2}{\pi} \cdot \frac{P}{L D}$

Dengan:

$\mathrm{ft} \quad=$ kuat tarik beton $\left(\mathrm{N} / \mathrm{m}^{2}\right)$

$\mathrm{P}=$ beban pada waktu belah $(\mathrm{N})$

$\mathrm{L} \quad=$ panjang benda uji silinder $(\mathrm{m})$

$\mathrm{D}=$ diameter benda uji silinder $(\mathrm{m})$

\section{Metode Penelitian}

\section{Tempat/Lokasi dan Waktu Penelitian}

Penelitian ini dilakukan di:

Tempat : Laboratorium Teknik Sipil Universitas Bangka Belitung.

Waktu : Lama penelitian terhitung sejak ujian proposal sampai dengan ujian pedadaran/sidang akhir.

\section{Bahan}

Bahan-bahan yang digunakan dalam penelitian beton ini adalah:semen, air, agregat(kasar dan halus), dan serat spanduk.

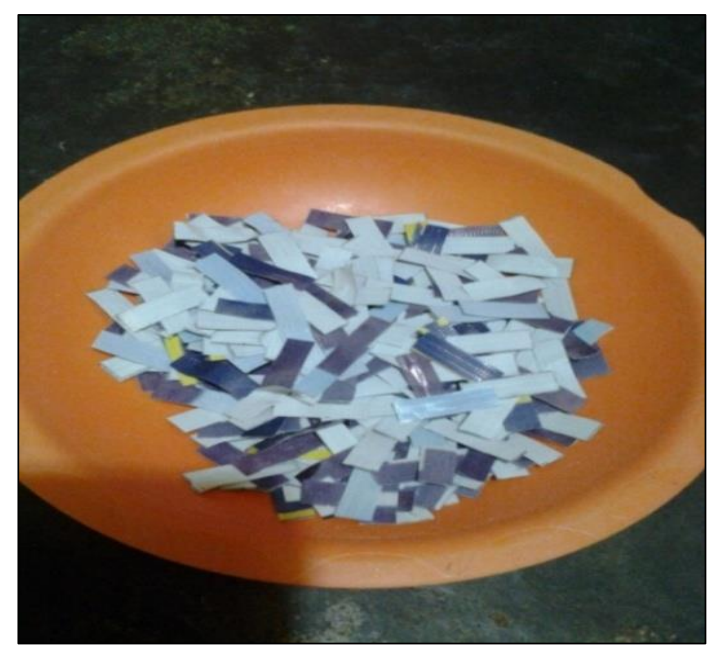

Gambar 1. Serat Spanduk 


\section{Kebutuhan Benda Uji}

Tabel 1. Kebutuhan Benda Uji Kuat Tekan dan Kuat Tarik Belah Beton

\begin{tabular}{|c|c|c|c|}
\hline \multirow{3}{*}{$\begin{array}{l}\text { Campuran Beton } \\
20 \mathrm{Mpa}\end{array}$} & \multicolumn{2}{|c|}{ Umur Beton } & \multirow{2}{*}{$\begin{array}{l}\text { Jumlah } \\
\text { Benda } \\
\text { Uji }\end{array}$} \\
\hline & $\begin{array}{l}\text { Kuat } \\
\text { Tekan }\end{array}$ & $\begin{array}{l}\text { Kuat } \\
\text { Tarik }\end{array}$ & \\
\hline & 28 hari & 28 hari & \\
\hline $\begin{array}{ll}0 \% & \text { Serat } \\
\text { Spanduk } & \end{array}$ & 3 & 3 & 6 \\
\hline $\begin{array}{ll}0,15 \% & \text { Serat } \\
\text { Spanduk } & \end{array}$ & 3 & 3 & 6 \\
\hline $\begin{array}{ll}0,45 \% & \text { Serat } \\
\text { Spanduk } & \end{array}$ & 3 & 3 & 6 \\
\hline Jumlah & & & 18 \\
\hline
\end{tabular}

Sumber : Hasil Perhitungan

\section{Alat}

Alat-alat yang digunakan pada penelitian ini adalah saringan, timbangan, kompor, cawan, sendok, piknometer, gelas ukur, kerucut terpancung, alat uji slump, batang baja, cetakan beton, mesin penguncang saringan, timbangan berat jenis, bak pengaduk, bak perendam, menis Los Angeles, pH digital, alat uji tekan, alat uji kuat tarik belah beton.

\section{Hasil dan Pembahasan}

\section{Hasil Pengujian Agregat Halus}

Tabel 2. Hasil Rekapitulasi Pengujian Agregat Halus

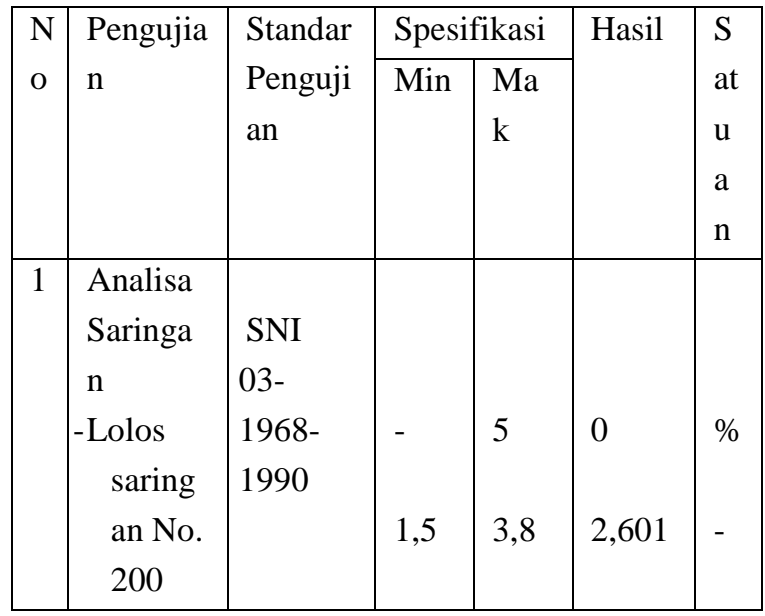

\begin{tabular}{|c|c|c|c|c|c|c|}
\hline \multirow{3}{*}{$\begin{array}{l}\mathrm{N} \\
\mathrm{O}\end{array}$} & \multirow{2}{*}{$\begin{array}{l}\text { Pengujia } \\
n\end{array}$} & \multirow{2}{*}{$\begin{array}{l}\text { Standar } \\
\text { Penguji } \\
\text { an }\end{array}$} & \multicolumn{2}{|c|}{ Spesifikasi } & \multirow[t]{2}{*}{ Hasil } & \multirow{2}{*}{$\begin{array}{l}\mathrm{S} \\
\text { at } \\
\mathrm{u} \\
\mathrm{a} \\
\mathrm{n}\end{array}$} \\
\hline & & & Min & $\mathrm{Ma}$ & & \\
\hline & \begin{tabular}{|l}
-Modulu \\
s \\
Kehal \\
usan
\end{tabular} & & & & & \\
\hline 2 & \begin{tabular}{|l} 
Berat \\
jenis \\
- Bulk \\
- SSD \\
- Appar \\
ent \\
- Penye \\
rapan \\
air
\end{tabular} & $\begin{array}{l}\text { SNI } \\
03- \\
1969- \\
1990\end{array}$ & $\begin{array}{l}2,5 \\
2,5 \\
2,5 \\
-\end{array}$ & $\begin{array}{l}- \\
- \\
- \\
3\end{array}$ & $\begin{array}{l}2,503 \\
2,541 \\
2,603 \\
1,537\end{array}$ & $\begin{array}{l}- \\
- \\
- \\
\%\end{array}$ \\
\hline 3 & $\begin{array}{c}\text { Berat isi } \\
\text { - Lepas } \\
\text { (silin } \\
\text { der) } \\
\text { - Padat } \\
\text { (silin } \\
\text { der) }\end{array}$ & $\begin{array}{l}\text { SNI } \\
03- \\
1973- \\
1990\end{array}$ & $\begin{array}{l}0,4 \\
0,4\end{array}$ & $\begin{array}{l}1,9 \\
1,9\end{array}$ & $\begin{array}{l}1,226 \\
1,377\end{array}$ & $\begin{array}{l}\text { gr } \\
\text { /c } \\
\mathrm{m} \\
3 \\
\mathrm{gr} \\
\text { /c }\end{array}$ \\
\hline 4 & $\begin{array}{l}\text { Kadar } \\
\text { air }\end{array}$ & $\begin{array}{l}\text { SNI } \\
03- \\
1971- \\
1990\end{array}$ & - & - & 0,898 & $\%$ \\
\hline
\end{tabular}

\section{Sumber : Hasil Pengujian}

Dari hasil rekapitulasi pengujian, agregat halus memenuhi spesifikasi yang telah ditentukan.

Tabel 3. Hasil Rekapitulasi Pengujian Agregat Kasar

\begin{tabular}{|c|c|c|c|c|c|c|}
\hline \multirow{2}{*}{$\begin{array}{l}\mathrm{N} \\
\mathrm{o}\end{array}$} & \multirow{2}{*}{$\begin{array}{l}\text { Penguji } \\
\text { an }\end{array}$} & \multirow{2}{*}{$\begin{array}{l}\text { Standar } \\
\text { Penguji } \\
\text { an }\end{array}$} & \multicolumn{2}{|c|}{ Spesifikasi } & \multirow[t]{2}{*}{ Hasil } & $\mathrm{Sa}$ \\
\hline & & & Min & $\begin{array}{l}\mathrm{Ma} \\
\mathrm{k}\end{array}$ & & $\begin{array}{l}\text { tu } \\
\text { an }\end{array}$ \\
\hline 1 & $\begin{array}{l}\text { Analisa } \\
\text { saringan } \\
\text {-Lolos } \\
\text { saringan } \\
\text { no. } 200\end{array}$ & $\begin{array}{l}\text { SNI } \\
03- \\
1968- \\
1990\end{array}$ & - & 1 & 0 & $\%$ \\
\hline
\end{tabular}




\begin{tabular}{|c|c|c|c|c|c|c|}
\hline \multirow{2}{*}{$\begin{array}{l}\mathrm{N} \\
\mathrm{o}\end{array}$} & \multirow{2}{*}{$\begin{array}{l}\text { Penguji } \\
\text { an }\end{array}$} & \multirow{2}{*}{$\begin{array}{l}\text { Standar } \\
\text { Penguji } \\
\text { an }\end{array}$} & \multicolumn{2}{|c|}{ Spesifikasi } & \multirow[t]{2}{*}{ Hasil } & \multirow{2}{*}{$\begin{array}{l}\text { Sa } \\
\text { tu } \\
\text { an }\end{array}$} \\
\hline & & & Min & $\begin{array}{l}\text { Ma } \\
k\end{array}$ & & \\
\hline & $\begin{array}{l}\text {-Modu } \\
\text { lus } \\
\text { kehalusa } \\
\mathrm{n}\end{array}$ & & 6 & 8 & 7,041 & - \\
\hline 2 & $\begin{array}{l}\text { Berat } \\
\text { jenis } \\
-B u l k \\
\text {-SSD } \\
\text {-Appa } \\
\text { Rent } \\
\text {-Peny } \\
\text { erapan } \\
\text { air }\end{array}$ & $\begin{array}{l}\text { SNI } \\
03- \\
1969- \\
1990\end{array}$ & $\begin{array}{l}2,5 \\
2,5 \\
2,5\end{array}$ & $\begin{array}{l}- \\
- \\
-\end{array}$ & $\begin{array}{r}2,612 \\
2,628 \\
2,655 \\
\\
0,899\end{array}$ & $\begin{array}{l}- \\
- \\
-\end{array}$ \\
\hline 3 & $\begin{array}{l}\text { Berat isi } \\
\text {-Lepas } \\
\text { (silinder } \\
\text { ) } \\
\text {-Padat } \\
\text { (silinder } \\
\text { ) }\end{array}$ & $\begin{array}{l}\text { SNI } \\
03- \\
1973- \\
1990\end{array}$ & 0,4 & 1,9 & 1,471 & $\begin{array}{l}\mathrm{gr} \\
\text { /c } \\
\mathrm{m} \\
3 \\
\\
\mathrm{gr} \\
\text { /c } \\
\mathrm{m}\end{array}$ \\
\hline 4 & $\begin{array}{l}\text { Kadar } \\
\text { air }\end{array}$ & $\begin{array}{l}\text { SNI } \\
03- \\
1971- \\
1990\end{array}$ & - & - & 0,568 & $\%$ \\
\hline 5 & $\begin{array}{l}\text { Keausan } \\
\text { agregat }\end{array}$ & $\begin{array}{l}\text { SNI } \\
03- \\
2417- \\
1991\end{array}$ & - & 40 & 2,570 & $\%$ \\
\hline
\end{tabular}

Sumber : Hasil Pengujian

Dari hasil rekapitulasi pengujian, agregat kasar memenuhi spesifikasi yang telah ditentukan.

\section{Hasil Pengujian pH Air}

Tabel 4. Pengujian $\mathrm{pH}$ Air

\begin{tabular}{|l|l|l|l|}
\hline No. & Uraian & Hasil & Suhu \\
\hline & $\mathrm{pH}$ air & $5,895 \quad(\mathrm{pH}$ & \\
& Laboratorium & meter & \\
1. & Teknik Sipil & digital) & $29,2^{\circ} \mathrm{c}$ \\
& Universitas & $5 \quad$ Kertas & \\
& Bangka Belitung & lakmus) & \\
\hline
\end{tabular}

Sumber : Hasil Pengujian

Tabel 5. Perhitungan Proporsi Campuran Beton

\begin{tabular}{|c|c|c|}
\hline No & Uraian & Nilai \\
\hline 1. & $\begin{array}{l}\text { Kuat tekan yang } \\
\text { diisyaratkan }\end{array}$ & $\begin{array}{l}20 \mathrm{~N} / \mathrm{mm}^{2} \text { (umur } \\
28 \text { hari) }\end{array}$ \\
\hline 2. & Deviasi standar & - \\
\hline 3. & Nilai tambah (margin) & $7,0 \mathrm{~N} / \mathrm{mm}^{2}$ \\
\hline 4. & $\begin{array}{l}\text { Kuat tekan rata-rata yang } \\
\text { ditargetkan }\end{array}$ & $27 \mathrm{~N} / \mathrm{mm}^{2}$ \\
\hline 5. & Jenis semen & Tipe I \\
\hline 6. & $\begin{array}{l}\text { Jenis agregat: } \\
\text { Kasar } \\
\text { Halus }\end{array}$ & $\begin{array}{l}\text { Batu pecah } \\
\text { Pasir alami }\end{array}$ \\
\hline 7. & Faktor air semen & 0,54 \\
\hline 8. & Nilai Slump & $60-180 \mathrm{~mm}$ \\
\hline 9. & Ukuran agregat maksimum & $40 \mathrm{~mm}$ \\
\hline 10. & Kebutuhan air & $185 \mathrm{lt} / \mathrm{m}^{3}$ \\
\hline 11. & Jumlah semen & $342,593 \mathrm{~kg} / \mathrm{m}^{3}$ \\
\hline 12. & $\begin{array}{l}\text { Susunan butir agregat } \\
\text { halus }\end{array}$ & $\begin{array}{l}\text { Daerah gradasi } \\
\text { susunan butir II }\end{array}$ \\
\hline 13. & Persen agregat halus & $38 \%$ \\
\hline 14. & $\begin{array}{l}\text { Berat jenis agregat } \\
\text { campuran }\end{array}$ & 2,475 \\
\hline 15. & Perkiraan berat beton & $2375 \mathrm{~kg} / \mathrm{m}^{3}$ \\
\hline 16. & $\begin{array}{l}\text { Kebutuhan berat agregat } \\
\text { campuran }\end{array}$ & $1847,407 \mathrm{~kg} / \mathrm{m}^{3}$ \\
\hline 17. & Kebutuhan agregat halus & $702,015 \mathrm{~kg} / \mathrm{m}^{3}$ \\
\hline 18. & Kebutuhan agregat kasar & $1145,392 \mathrm{~kg} / \mathrm{m}^{3}$ \\
\hline
\end{tabular}

Sumber : Hasil Perhitungan

Tabel 6. Hasil Perhitungan Campuran Beton

Tiap 6 Silinder Dalam 1 Kali Pengadukan

Dengan Potongan Limbah Spanduk Sebagai

Bahan Tambah 


\begin{tabular}{|l|l|l|l|}
\hline $\begin{array}{l}\text { Tiap 0,032 } \mathrm{m}^{3} \\
(6 \text { silinder) }\end{array}$ & $0 \%$ & $\begin{array}{l}0,15 \% \\
\mathrm{SS}\end{array}$ & $\begin{array}{l}0,45 \% \\
\mathrm{SS}\end{array}$ \\
\hline Semen $(\mathrm{kg})$ & 10,963 & 10,963 & 10,963 \\
\hline $\begin{array}{l}\text { Agregat Kasar } \\
(\mathrm{kg})\end{array}$ & 36,634 & 36,634 & 36,634 \\
\hline $\begin{array}{l}\text { Agregat Halus } \\
(\mathrm{kg})\end{array}$ & 22,677 & 22,677 & 22,677 \\
\hline Air (lt) & 5,726 & 5,726 & 5,726 \\
\hline $\begin{array}{l}\text { Serat } \\
\text { Banner/Spanduk }\end{array}$ & 0 & 0,114 & 0,342 \\
\hline
\end{tabular}

Tabel 7. Hasil Pengujian Slump

\begin{tabular}{|l|l|}
\hline $\begin{array}{l}\text { Persentase ban karet } \\
\text { dan serat } \\
\text { polypropylene }\end{array}$ & $\begin{array}{l}\text { Nilai } \\
\text { slump } \\
\text { rata-rata }\end{array}$ \\
\hline $0 \%$ Serat Spanduk & 7,9 \\
\hline $\begin{array}{l}0,15 \% \text { Serat } \\
\text { Spanduk }\end{array}$ & 7,2 \\
\hline $0,45 \%$ Serat Spanduk & 6,35 \\
\hline
\end{tabular}

Sumber : Hasil Pengujian

Sumber : Hasil Perhitungan

Dimana :

SS $=$ Serat Spanduk

Data dari hasil pengujian slump beton yang dilakukan dapat dilihat pada Tabel 4.21

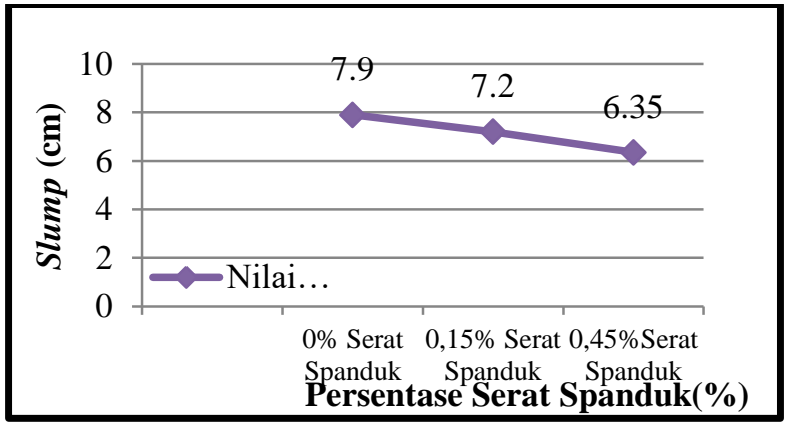

Gambar 2. Hubungan antara nilai slump dengan nilai persentase penambahan spanduk

Tabel 8. Hasil Pengujian Kuat Tekan beton pada Umur 7 Hari

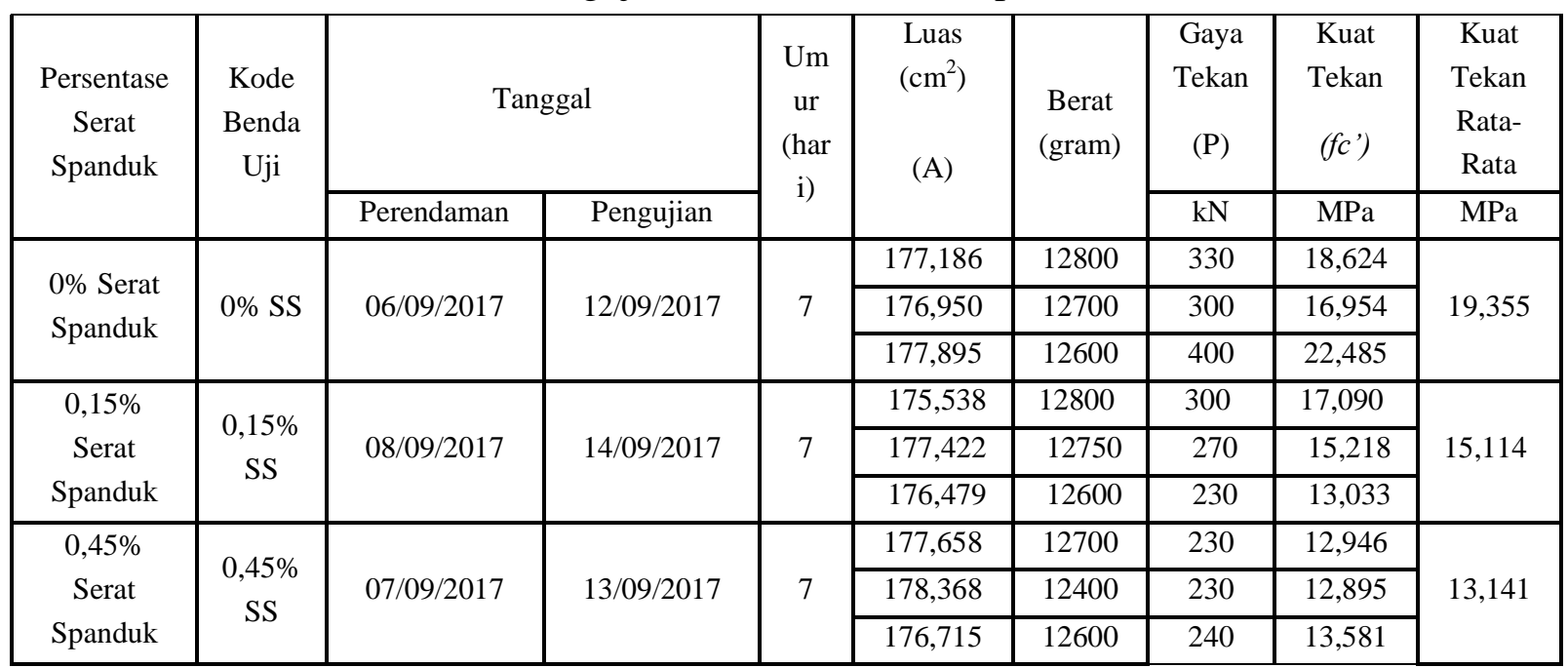

Sumber : Hasil Pengujian

Tabel 9. Hasil Pengujian Kuat Tekan Beton Umur 28 Hari

\begin{tabular}{|c|c|c|c|c|c|c|c|c|c|}
\hline \multirow{2}{*}{$\begin{array}{c}\text { Persentase } \\
\text { Serat } \\
\text { Spanduk }\end{array}$} & \multirow{2}{*}{$\begin{array}{c}\text { Kode } \\
\text { Benda } \\
\text { Uji }\end{array}$} & \multicolumn{2}{|c|}{ Tanggal } & \multirow{2}{*}{$\begin{array}{l}\text { Umur } \\
\text { (hari) }\end{array}$} & \multirow{2}{*}{$\begin{array}{l}\text { Luas } \\
\left(\mathrm{cm}^{2}\right) \\
\text { (A) }\end{array}$} & \multirow{2}{*}{$\begin{array}{l}\text { Berat } \\
\text { (gram) }\end{array}$} & $\begin{array}{c}\text { Gaya } \\
\text { Tekan }\end{array}$ & $\begin{array}{c}\text { Kuat } \\
\text { Tekan }\end{array}$ & $\begin{array}{c}\text { Kuat } \\
\text { Tekan }\end{array}$ \\
\hline & & Perendaman & Pengujian & & & & $\mathrm{kN}$ & $\mathrm{MPa}$ & $\mathrm{MPa}$ \\
\hline \multirow{2}{*}{$\begin{array}{l}0 \% \text { Serat } \\
\text { Spanduk }\end{array}$} & \multirow{2}{*}{$0 \% \mathrm{SS}$} & \multirow{2}{*}{$17 / 09 / 2017$} & \multirow{2}{*}{$14 / 10 / 2017$} & \multirow{2}{*}{28} & 174,835 & 12600 & 350 & 20,019 & \multirow{2}{*}{20,413} \\
\hline & & & & & 188,692 & 12500 & 410 & 21,729 & \\
\hline
\end{tabular}




\begin{tabular}{|c|c|c|c|c|c|c|c|c|c|}
\hline \multirow{3}{*}{$\begin{array}{c}\text { Persentase } \\
\text { Serat } \\
\text { Spanduk }\end{array}$} & \multirow{3}{*}{$\begin{array}{c}\text { Kode } \\
\text { Benda } \\
\text { Uji }\end{array}$} & \multicolumn{2}{|c|}{ Tanggal } & \multirow{3}{*}{$\begin{array}{l}\text { Umur } \\
\text { (hari) }\end{array}$} & \multirow{2}{*}{$\begin{array}{l}\text { Luas } \\
\left(\mathrm{cm}^{2}\right) \\
\text { (A) }\end{array}$} & \multirow{2}{*}{$\begin{array}{c}\text { Berat } \\
\text { (gram) }\end{array}$} & $\begin{array}{l}\text { Gaya } \\
\text { Tekan }\end{array}$ & \multirow{2}{*}{$\begin{array}{c}\text { Kuat } \\
\text { Tekan } \\
\left(f c^{\prime}\right) \\
\mathrm{MPa}\end{array}$} & \multirow{2}{*}{$\begin{array}{c}\begin{array}{c}\text { Kuat } \\
\text { Tekan } \\
\text { Rata-Rata }\end{array} \\
\mathrm{MPa} \\
\end{array}$} \\
\hline & & Perendaman & Pengujian & & & & $\mathrm{kN}$ & & \\
\hline & & & & & 179,553 & 12500 & 350 & 19,493 & \\
\hline \multirow{3}{*}{$\begin{array}{c}0,15 \% \\
\text { Serat } \\
\text { Spanduk }\end{array}$} & \multirow{3}{*}{$\begin{array}{c}0,15 \% \\
\mathrm{SS}\end{array}$} & \multirow{3}{*}{ 18/09/2017 } & \multirow{3}{*}{$15 / 10 / 2017$} & \multirow{3}{*}{28} & 174,835 & 12400 & 270 & 15,443 & \multirow{3}{*}{17,985} \\
\hline & & & & & 176,008 & 12400 & 325 & 18,465 & \\
\hline & & & & & 174,600 & 12500 & 350 & 20,046 & \\
\hline \multirow{3}{*}{$\begin{array}{c}0,45 \% \\
\text { Serat } \\
\text { Spanduk }\end{array}$} & \multirow{3}{*}{$\begin{array}{c}0,45 \% \\
\text { SS }\end{array}$} & \multirow{3}{*}{$19 / 09 / 2017$} & \multirow{3}{*}{$15 / 10 / 2017$} & \multirow{3}{*}{28} & 181,458 & 12200 & 250 & 13,777 & \multirow{3}{*}{12,942} \\
\hline & & & & & 177,895 & 12500 & 220 & 12,367 & \\
\hline & & & & & 177,422 & 12600 & 225 & 12,682 & \\
\hline
\end{tabular}

Sumber : Hasil Pengujian

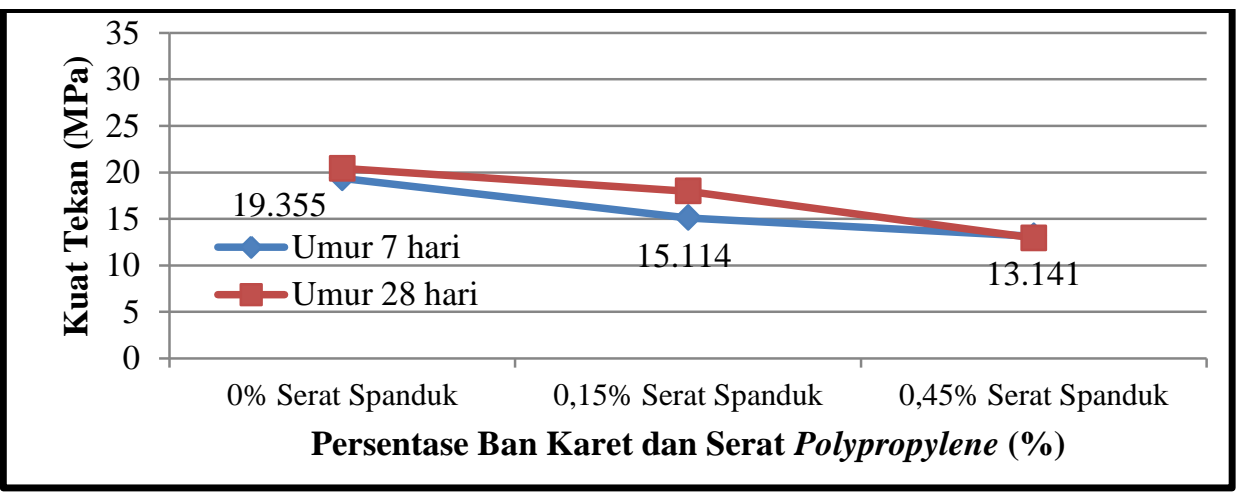

Gambar 3. Hubungan nilai kuat tekan beton umur 7 hari dan 28 hari dengan menggunakan potongan limbah Spanduk

\section{Hasil Pengujian Kuat Tarik Belah Beton}

Tabel 4.25 Hasil Pengujian Kuat Tarik Belah Beton pada Umur 28 Hari

\begin{tabular}{|c|c|c|c|c|c|c|c|c|c|}
\hline \multirow{2}{*}{$\begin{array}{l}\text { Persentase Serat } \\
\text { Spanduk/Banner }\end{array}$} & \multirow{2}{*}{$\begin{array}{c}\text { Kode } \\
\text { Benda } \\
\text { Uji }\end{array}$} & \multicolumn{2}{|c|}{ Tanggal } & \multirow{2}{*}{$\begin{array}{l}\text { Umur } \\
\text { (hari) }\end{array}$} & \multirow{2}{*}{$\begin{array}{l}\text { Luas } \\
\left(\mathrm{cm}^{2}\right) \\
\text { (A) }\end{array}$} & \multirow{2}{*}{$\begin{array}{l}\text { Berat } \\
\text { (gram) }\end{array}$} & $\begin{array}{l}\text { Gaya } \\
\text { Tarik }\end{array}$ & $\begin{array}{l}\text { Kuat } \\
\text { Tarik }\end{array}$ & \multirow{2}{*}{$\begin{array}{l}\text { Kuat } \\
\text { Tarik } \\
\text { Rata- } \\
\text { Rata } \\
\text { Mpa }\end{array}$} \\
\hline & & Perendaman & Pengujian & & & & $\mathrm{kN}$ & $\mathrm{MPa}$ & \\
\hline \multirow{3}{*}{$\begin{array}{l}0 \% \text { Serat } \\
\text { Spanduk }\end{array}$} & \multirow{3}{*}{$0 \% \mathrm{SS}$} & \multirow{3}{*}{$14 / 10 / 2017$} & \multirow{3}{*}{$02 / 08 / 2017$} & \multirow{3}{*}{28} & 1394,854 & 12600 & 200 & 2,868 & \multirow{3}{*}{2,467} \\
\hline & & & & & 1410,310 & 12600 & 160 & 2,269 & \\
\hline & & & & & 1413,245 & 12600 & 160 & 2,264 & \\
\hline \multirow{3}{*}{$\begin{array}{c}0,15 \% \text { Serat } \\
\text { Spanduk }\end{array}$} & \multirow{3}{*}{$\begin{array}{c}0,15 \% \\
\text { SS }\end{array}$} & \multirow{3}{*}{$15 / 10 / 2017$} & \multirow{3}{*}{ 03/08/2017 } & \multirow{3}{*}{28} & 1419,362 & 12400 & 155 & 2,184 & \multirow{3}{*}{2,161} \\
\hline & & & & & 1425,521 & 12500 & 155 & 2,175 & \\
\hline & & & & & 1413,241 & 12500 & 150 & 2,123 & \\
\hline \multirow{3}{*}{$\begin{array}{l}0,45 \% \text { Serat } \\
\text { Spanduk }\end{array}$} & \multirow{3}{*}{$\begin{array}{c}0,45 \% \\
\text { SS }\end{array}$} & \multirow{3}{*}{$16 / 10 / 2017$} & \multirow{3}{*}{ 07/08/2017 } & \multirow{3}{*}{28} & 1433,999 & 12600 & 160 & 2,232 & \multirow{3}{*}{2,220} \\
\hline & & & & & 1422,199 & 12700 & 165 & 2,320 & \\
\hline & & & & & 1423,141 & 12400 & 150 & 2,108 & \\
\hline
\end{tabular}

Sumber : Hasil Pengujian 


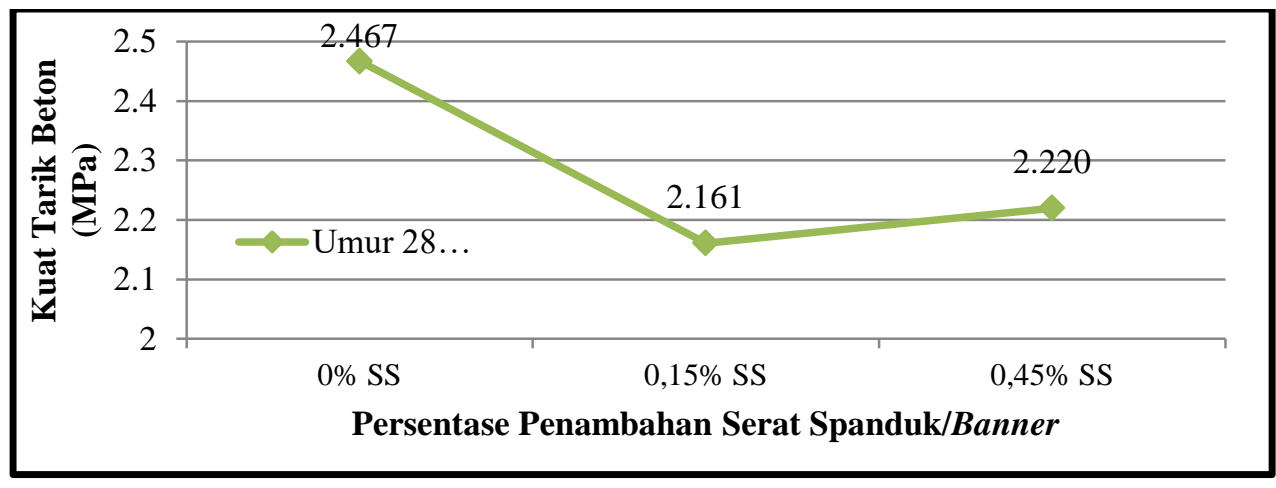

Gambar 4.10 Hubungan nilai kuat tarik belah beton umur 28 hari dengan menggunakan potongan limbah Spanduk

\section{Kesimpulan dan Saran}

\section{Kesimpulan}

Hasil pengujian penambahan bahan tambah berupa serat spandukdalam pembuatan beton sebagai berikut :

1. Nilai kuat tekan beton dengan menggunakan potongan kimbah spanduk sebagai bahan tambah dari pembuatan beton didapat hasil sebagai berikut : Kuat tekan beton pada umur 7 hari pada persentase 0\% SS sebesar $19,355 \mathrm{MPa}$, persentase $0,15 \%$ SS sebesar 15,114 MPa, pada persentase 0,45\% SS sebesar 13,141 MPa. Hasil kuat tekan yang didapat mengalami penurunan pada penambahan serat spanduk jika dibandingkan dengan beton normal atau 0\% SS. Sedangkan kuat tekan beton pada umur 28 hari pada persentase $0 \%$ SS sebesar 20,413 $\mathrm{MPa}$, persentase $0,15 \%$ SS sebesar $17,985 \mathrm{MPa}$, pada persentase $0,45 \% \mathrm{SS}$ sebesar 12,942 MPa. Hasil kuat tekan yang didapat mengalami penurunan pada penambahan serat spanduk jika dibandingkan dengan beton normal atau 0\% SS. Serat spanduk tidak bisa digunakan sebagai bahan tambah pada beton.
2. Nilai kuat tarik belah beton dengan menggunakan potongan limbah spanduk sebagai bahan dari beton didapat hasil pada pengujian beton umur 28 hari pada persentase 0\% SS sebesar 2,467 $\mathrm{MPa}$, pada persentase 0,15\% SS sebesar 2,161 MPa, pada persentase $0,45 \%$ SS sebesar 2,220 MPa. Hasil pada kuat tarik belah beton mengalami penurunan jika dibandingkan dengan beton normal atau $0 \%$ SS. Serat spanduk tidak bisa digunakan sebagai bahan tambah pada beton.

\section{Saran}

1. Perlu dilakukan variasi bentuk dan ukuran dari serat spanduk, misalnya berbentuk persegi, persegi panjang dengan ukuran yang lebih kecil misalnya dengan ukuran $1 \mathrm{~cm} \times 2 \mathrm{~cm}$ atau $0,5 \mathrm{~cm} \times 1 \mathrm{~cm}$, atau dengan bentuk bulat dengan ukuran yang homogen, agar diantara serat spanduk dan pasta semen terjadi saling mengikat, arah serat juga perlu diperhatikan.

\section{DAFTAR PUSTAKA}

Anonim,PBI 1971-N.I - 2 
Anonim, SNI 03-1968-1990., Metode Pengujian Tentang Analisis Saringan Agregat Halus dan Kasar, Pusjatan Balitbang PU

Anonim, SNI 03-1969-2008., Cara Uji Berat Jenis dan PenyerapanAir Agregat Kasar,

Anonim, SNI 03-1970-2008., Cara Uji Berat Jenis dan PenyerapanAir Agregat Kasar,

Anonim, SNI 03-1973-1990., Metode Pengujian Berat Isi Beton,

Anonim, SNI 03-1971-1990., Metode Pengujian Kadar Air Agregat,

Anonim, SNI 03-2417-2008., Cara Uji Keausan Agregat Kasar dengan Mesin Los Angeles,

Anonim, SNI 03-1972-1990., Metode Pengujian Slump Beton,

Anonim, SNI 03-1974-1990., Metode Pengujian Kuat Tekan Beton,

Anonim, SNI 03-2491-2002., Metode Pengujian Kuat Tarik Belah Beton,

Anonim, SNI 03-2834-2002., Tata Cara Pembuatan Rencana Campuran beton Normal

Anonim, SNI 03-2847-2000., Tata Cara Perhitungan Struktur Beton Untuk Bangunan Gedung

Apriliawati,A.,2016,Kajian Kuat Lekat dan Kuat Tekan Pada Beton Serat Dengan Bahan Tambah Potongan Limbah Banner, Jurnal Universitas Sebelas Maret, Surakarta

HAriyanti, N,F.,2016, Pengaruh Variasi Bentuk Potongan Limbah Banner Terhadap Kelecakan dan Kuat Lentur Beton Serat Banner, Jurnal Universitas Sebelas Maret, Surakarta
Putri, R, N, C., 2016,Pengaruh Penambahan Potongan Limbah Banner dengan bentuk Potongan Memanjang Terhadap Kuat Tekan dan Kuat Lentur Beton, Jurnal Universitas Sebelas Maret, Surakarta

Pratama, E., 2016, Kajian Kuat Tekan dan Kuat Tarik Belah Beton Kertas (Papercrete) dengan Bahan Tambah Serat Nylon, Tugas Akhir, Universitas Bangka Belitung

Suryawan, N.,Pengaruh Penambahan Serat Polypropylene Pada Beton Ringan dengan Teknologi Foam Terhadap Kuat Tekan dann Kuat Tarik BElah dan Modulus Elastisitas, Jurnal, Universitas Sebelas Maret, Surakarta

Tjokrodimuljo, K.,2007, Teknologi Beton, Teknik Sipil Universitas Gadjah Mada 